\title{
Narasi Korban Perkosaan pada Pemberitaan di Media Daring RRI Samarinda: Analisis Wacana Kritis Model Sara Mills
}

\section{The narrative of rape victims in online news RRI Samarinda: Critical discourse analysis Sara Mills model}

\author{
Nina Queena Hadi Putri', Firstya Evi Dianastiti2,", dan Sumarlam ${ }^{3}$ \\ 1Universitas Mulawarman, Jalan Kuaro, Gn. Kelua, Kec. Samarinda Ulu, Kota Samarinda, Kalimantan Timur, Indonesia \\ Email: ninaqueenahadiputri@student.uns.ac.id; Orcid: https://orcid.org/0000-0001-6907-6044 \\ 2, Universitas Tidar, Jalan Kapten Suparman No. 39, Kec. Magelang Utara, Kota Magelang, Jawa Tengah, Indonesia \\ Email: dianastiti_firstya@student.uns.ac.id; Orcid: https://orcid.org/0000-0003-2395-175X \\ 3Universitas Sebelas Maret, Jalan Ir. Sutami No.36, Kentingan, Kec. Jebres, Kota Surakarta, Jawa Tengah, Indonesia \\ Email: sumarlam@staff.uns.ac.id; Orcid: https://orcid.org/0000-0001-9370-0425
}

\begin{tabular}{|c|c|}
\hline $\begin{array}{l}\text { ARTICLE HISTORY } \\
\text { Received } 15 \text { October } 2021 \\
\text { Accepted } 01 \text { December } 2021 \\
\text { Published } 1 \text { February } 2022 \\
\text { KEYWORDS } \\
\text { rape victims, mass media, } \\
\text { critical discourse analysis, Sara } \\
\text { Mills. } \\
\text { KATA KUNCI } \\
\text { perkosaan, media massa, } \\
\text { analisis wacana kritis, Sara } \\
\text { Mills. }\end{array}$ & 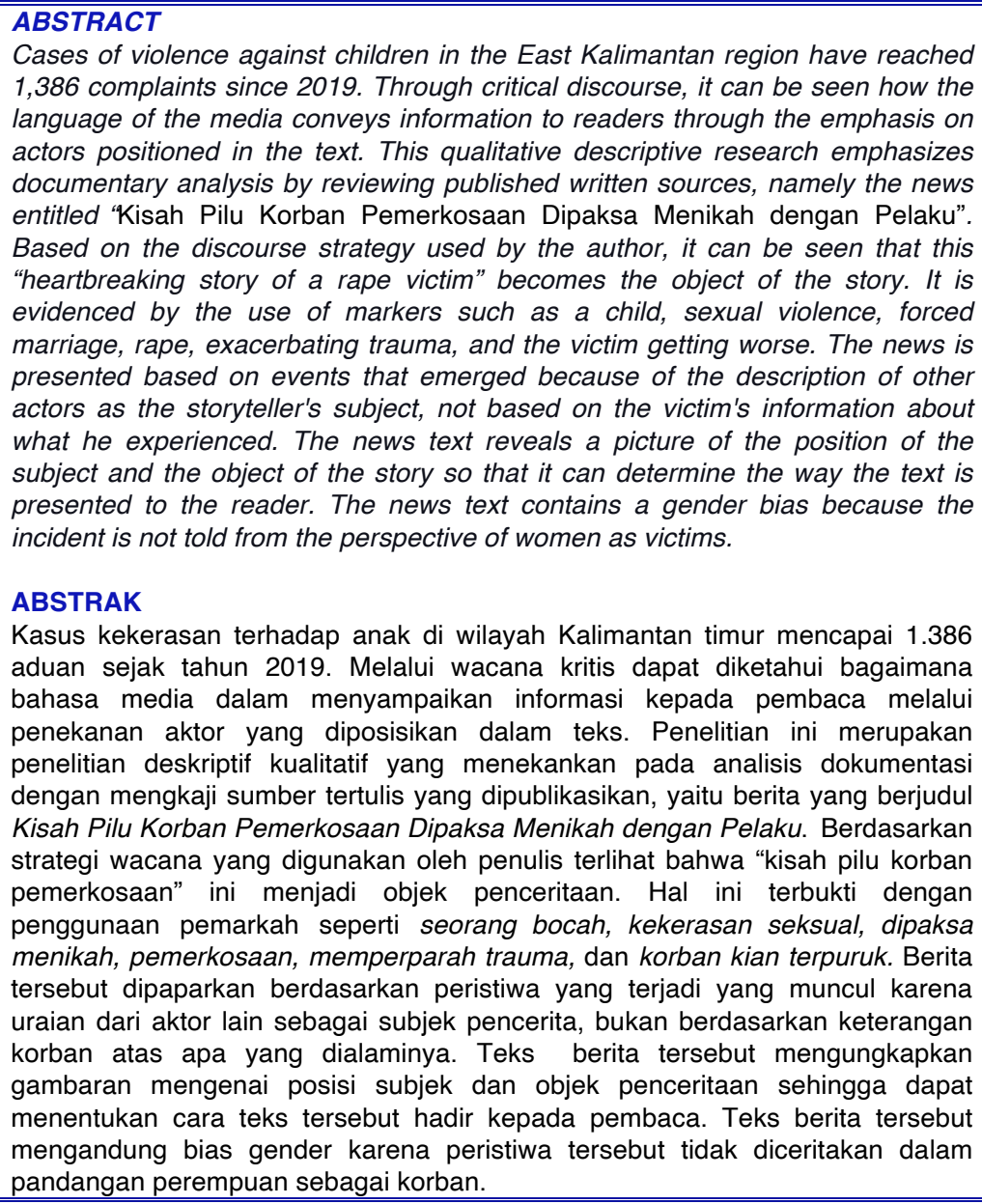 \\
\hline
\end{tabular}

To cite this article:

Putri, N. Q. H., Dianastiti, F. E., \& Sumarlam, S. (2022). Narasi Korban Perkosaan pada Pemberitaan di Media Daring RRI Samarinda: Analisis Wacana Kritis Model Sara Mills. Diglosia: Jurnal Kajian Bahasa, Sastra, dan Pengajarannya, 5(1), 1-12. https://doi.org/10.30872/diglosia.v5i1.313 


\section{A. Pendahuluan}

Dewasa ini, peran teknologi sangat besar dalam penyebaran dan pencarian informasi. Pemberitaan dalam media massa dalam jaringan (online) menjadi salah satu media informasi yang dipilih oleh masyarakat karena dapat diakses dengan mudah tanpa terhalang ruang dan waktu. Namun, disadari maupun tidak, pada dasarnya bahasa pada suatu wacana di surat kabar tidaklah netral, tetapi memiliki hubungan khusus dengan kelompok atau kekuatan yang dominan.

Selain itu, surat kabar juga menjadi representasi simbolis dan nilai masyarakat telah membentuk stereotip yang sering melakukan pemarginalan, merugikan pihak tertentu dengan citra yang negatif dan memosisikan pihak lain dengan citra yang positif, pemarginalan tersebut dilakukan dengan bagaimana suatu aktor ditekankan dalam teks. Pemosisian tersebut berdasarkan pensubjek-an di satu pihak sebagai penafsir dan objek sebagai pihak yang ditafsirkan (Badara, 2014). Posisi wartawan dan media dalam keseluruhan struktur sosial dan kekuatan sosial yang ada dalam teks akan dikaji berdasarkan paradigma kritis (Eriyanto, 2015).

Penelitian ini bertujuan untuk mendeskripsikan bagaimana posisi perempuan ditampilkan dalam teks dengan objek penelitian berupa berita di media massa RRI Samarinda yang dimuat secara daring dengan judul Kisah Pilu Korban Pemerkosaan Dipaksa Menikah dengan Pelaku menggunakan teori analisis wacana kritis dengan pendekatan Kajian Sara Mills sehingga dapat mengungkapkan bagaimana bahasa media dalam menyampaikan informasi kepada pembaca melalui penekanan aktor yang diposisikan dalam teks. Kajian Sara Mills dipilih karena dapat menghubungkan antara teks dengan penulis dan teks dengan pembaca, sehingga dapat lebih kompleks dalam memahami suatu teks yang tidak hanya berkaitan pada produksi tetapi juga resepsi, kemudian menempatkan pembaca sebagai bagian yang penting karena teks merupakan bagian suatu media untuk berkomunikasi kepada khalayak dengan segala ragam kata sapaannya (Badara, 2014).

Selain itu, kajian Mills lebih memusatkan pada gender dan pemosisian pembaca sebab laki-laki dan perempuan memiliki perbedaan persepsi dalam membaca suatu teks dan menempatkan posisi dirinya dalam teks. Selain itu, Mills juga menyatakan bahwa gerakan perempuan itu penting bagi banyak perempuan dalam memetakan peran diskursif baru baik untuk laki-laki dan wanita. The Women's Movement has been important for many women in mapping out new discursive roles both for men and women. These roles are strongly contested by media representations and by the representations which are constructed through people's interactions with stereotypes of all kinds. But this type of critical knowledge has fundamentally changed and represented what it means to exist as a gendered subject (Mills, 2001). Peran analisis wacana kritis dalam sebuah media adalah tentang bagaimana mengembangkan fakta yang ada di lapangan dengan menganalisisnya ke dalam praktik sosial yang berkembang di masyarakat (Novianty \& Burhanudin, 2020). 
Eriyanto (2015) menyatakan bahwa dengan menggunakan analisis wacana kritis Sara Mills, peneliti menelaah bagaimana perempuan ditampilkan dalam teks berita dengan menunjukkan bagaimana teks bias dalam menampilkan wanita, memaparkan bagaimana perempuan digambarkan, dan bagaimana bentuk yang dilakukan. Selain itu, peneliti akan menguraikan teks-teks yang menyudutkan pihak perempuan dengan menjabarkan bagaimana aktor tersebut dimunculkan dalam teks dengan menguraikan posisi subjek dan objek penceritaan serta pembaca dan penulis. Melalui analisis wacana, teks pada media memberikan pandangan secara menyeluruh pada berita yang bukan hanya pada proses produksi, tetapi juga struktur sosialnya (Eriyanto, 2015). Dalam surat kabar, bahasa dapat memberikan citra pada realitas media maupun khalayak (Badara, 2014).

Artikel ini difokuskan pada wacana feminisme yang menjelaskan bagaimana posisi perempuan ditampilkan dalam teks. Hal ini dilakukan karena banyaknya berita dengan menekankan pada perempuan sebagai objek penceritaan (Sobari \& Faridah, 2012). Ketertindasan yang dialami oleh kaum perempuan dianggap sebagai dampak dari mengakarnya sistem patriarki di tubuh masyarakat (Lesmana et al., 2021). Dibandingkan dengan laki-laki, perempuan acapkali ditampilkan sebagai sosok yang lemah dan dimarginalkan. Citra buruk yang ditampilkan secara tidak adil inilah yang menjadi perhatian utama dalam penulisan artikel ini. Mintarsih (2019) dalam penelitiannya Media Coverage of a Shelter for Abandoned Children in Indonesia: A Feminist Critical Discourse Analysis of the Representation of Female Migrant Workers menyimpulkan bahwa media seringkali tidak memiliki perspektif gender ketika memberitakan perihal tenaga kerja wanita terlebih yang merupakan TKI luar negeri. Hasil penelitian tersebut menjadi salah satu acuan yang digunakan dalam menganalisis data dalam penelitian ini dikarenakan memiliki dasar teori dan metode penelitian yang sama, yaitu analisis wacana kritis yang berfokus pada gender.

\section{B. Metode}

Penelitian ini merupakan penelitian deskriptif kualitatif yang menekankan pada analisis dokumentasi dengan mengkaji sumber tertulis dengan objek penelitian berupa berita yang berjudul Kisah Pilu Korban Pemerkosaan Dipaksa Menikah dengan Pelaku. Berita tersebut dimuat secara daring (online) dalam laman rri.co.id ${ }^{1}$. Berita tersebut dirilis pada tanggal 23 Juni 2021 Analisis terhadap pemberitaan tersebut dipilih karena adanya tokoh perempuan sebagai korban perkosaan berusia 13 tahun dalam pemberitaan yang merupakan bagian dari objek kajian Sara Mills dengan berbasis gender. Analisis wacana kritis Sara Mills memiliki beberapa fokus analisis, yaitu: (a) posisi subjek-objek, (b) posisi pembaca (pendengar), dan (c) posisi media.

Pengumpulan data dilakukan dengan membaca secara intensif, mencatat hal-hal yang berkaitan dengan objek penelitian, dan melakukan studi pustaka. Analisis data dalam artikel ini dengan menggunakan analisis wacana kritis Sara

1https://rri.co.id/samarinda/sosbud/feature/1088585/kisah-pilu-korban-pemerkosaan-dipaksa-menikah-dengan-pelaku 
Mills, yang memusatkan bagaimana suatu teks menempatkan posisi subjek objek maupun posisi pembaca. Data yang telah disusun secara sistematis kemudian dianalisis dengan menggunakan teori analisis wacana kritis Sara Mills berdasarkan posisi subjek objek maupun pembaca kemudian menjelaskan bagaimana perempuan diinterpretasikan dalam berita tersebut dan posisi yang menjelaskan siapa yang menjadi pencerita dalam teks.

\section{Pembahasan}

Isu gender pada perempuan sudah sejak lama muncul dari masyarakat tradisional yang memberikan pandangan bahwa perempuan hanya berperan sebagai ibu rumah tangga dengan pergerakan yang hanya terbatas pada kehidupan sosial di sekitar rumah dan keluarga. Pandangan tersebutlah yang menyebabkan perempuan dianggap tidak memiliki kelayakan sebagai seorang pemimpin (Sobari \& Faridah, 2012). Stereotip ini tidak hanya terjadi di Indonesia saja, tetapi berdasarkah hasil penelitian hal ini telah menjadi anggapan yang dianggap normal secara global. Hal ini diperkuat dengan pernyataan (Kiprotich \& Chang 'orok, 2015) yang menyatakan bahwa stereotip gender juga terjadi karena diperkuat oleh fitur budaya dan sosial ekonomi. Perempuan dipandang sebagai jenis kelamin yang lebih lemah, mudah didominasi oleh laki-laki maskulin yang kuat secara fisik, terkendali secara emosional dan yang juga mampu menafkahi keluarga mereka.

Peran dan posisi pada perempuan dan laki-laki menyebabkan stereotip gender kian terbentuk. Wanita dipandang sebagai jenis kelamin yang lebih lemah, dengan mudah didominasi oleh laki-laki maskulin yang kuat secara fisik, terkendali secara emosional dan juga mampu menyediakan untuk keluarga mereka. Stereotip gender berada di sepanjang garis yang berbeda yang ditentukan sebelumnya oleh ras, usia, kebangsaan, kelas sosial dan tingkat pendidikan di antara faktor-faktor lainnya. Stereotip inilah yang menyebabkan posisi perempuan pada media dieksploitasi secara negatif. Perempuan dipandang sebagai pihak yang lemah dan tidak berdaya. Pandangan masyarakat terhadap stereotip bahwa laki-laki menempati wilayah di sebelah kiri dengan keidentikan aktif, beradab, rasional, dan cerdas sedangkan perempuan berada di wilayah sebelah kanan dengan gambaran yang pasif, emosional, dekat dengan alam, dan kurang cerdas. Hal inilah yang menyebabkan perempuan dengan mudah dieksploitasi oleh media (Mills, 2001).

Selama stereotip terhadap perempuan seperti ini masih terus dipercaya oleh masyarakat, maka ketidakadilan atau diskriminasi terhadap perempuan terus saja ditampilkan oleh media walaupun sudah ada paham feminisme. Kementerian Pemberdayaan Perempuan dan Perlindungan Anak Republik Indonesia menyampaikan bahwa segala bentuk ketidakadilan gender bermula pada kesamaan sumber kekeliruan, yaitu mengenai stereotip gender pada lakilaki dan perempuan ((Novianty dan Burhanudin, 2020:75). Bahkan pada penelitian lain disebutkan bahwa salah satu film yang digemari dan ramah anak, yaitu film-film produksi Disney juga turut menyumbangkan fondasi 
terhadap pembangunan stereotip tersebut, "Most Disney films, especially the ones produced in earlier years, depict traditional gender roles. Men are often depicted as adventurous, physically strong, and brave, whereas women are typically shown to be physically attractive, affectionate, and even troublesome (Dawn et al., 2011).

Selain itu, persoalan kejahatan seksual dapat ditinjau sebagai akibat dari relasi sosial, baik relasi antarlingkungan dengan masyarakat ataupun laki-laki dengan perempuan. Praktik selama ini mengakibatkan kecenderungan memandang suatu kejahatan seksual dalam bentuk "keinginan seksual" dan akan berubah menjadi sudut pandang kejahatan seksual sebagai bentuk "dominasi seksual". Berawal dari perspektif seperti inilah, hukum apositif yang mengatur tentang kejahatan seksual dapat dilihat. Dari kejadian tersebut tentunya perempuan akan memikul akibat dari itu, apalagi sampai ia mengandung di luar pernikahan. Hal tersebut menunjukkan bagaimana rendahnya penghargaan laki-laki kepada perempuan dengan memosisikan perempuan hanya sebagai objek pemuas kebutuhan biologis (Novianty \& Burhanudin, 2020).

Diskriminasi dan hambatan kemajuan pada kaum perempuan disebabkan adanya kekerasan pada perempuan (pasal 2) yang mencakup (a) kekerasan secara fisik, maupun seksual, dan psikologis yang terjadi di dalam keluarga. Pemukulan, penyalahgunaan seksual terhadap anak dan perempuan dalam lingkup rumah tangga, kekerasan yang berkaitan dengan perkosaan dalam ikatan perkawinan, perusakan atau penganiayaan pada alat kelamin perempuan dan kekejaman lain seperti kekerasan di luar hubungan suami istri dan kekerasan yang berkaitan dengan eksploitasi. (b) kekerasan secara fisik, seksual, psikologis pada masyarakat luas yaitu pelecehan, pemerkosaan, penyalahgunaan seksual, maupun ancaman seksual yang terjadi di lingkungan kerja, Lembaga Pendidikan, dsb. Termasuk juga kekerasan yang berkaitan dengan perdagangan perempuan maupun pelacuran paksa. (c) kekerasan secara fisik, maupun seksual, dan psikologis yang dibenarkan oleh negara di lokasi mana pun (Novianty \& Burhanudin, 2020).

Sumber pemberitaan dengan menitikberatkan kekerasan pada perempuan di media masa dapat dianalisis dengan menggunakan analisis wacana kritis Sara Mills yang menekankan pada feminisme untuk menunjukkan bagaimana Wanita ditampilkan secara bias dalam teks. Perbedaan gagasan dari Sara Mills berbeda dengan model critical linguistic yang hanya memusatkan perhatian pada struktur kebahasaan dan bagaimana pengaruhnya dalam pemaknaan khalayak. Metode ini hanya meninjau struktur kebahasaan tanpa melihat bagaimana tokoh dalam pemberitaan tersebut ditampilkan, apakah ia memiliki ruang yang sama untuk berpendapat atau hanya meninjau dari satu sisi sudut pandang saja. Sedangkan Sara Mills (dalam Eriyanto, 2015)lebih memusatkan bagaimana peran pelaku, pembaca, dan penulis ditampilkan dalam teks. Gaya pemaparan dan peran yang diposisikan dalam teks akan membentuk pihak yang mengarah pada posisi legitimasi dan sebaliknya. Pemosisian seseorang sebagai penafsir dan posisi yang ditafsirkan akan menunjukkan bagaimana aktor tersebut diposisikan dalam teks. Peran teks dalam memosisikan subjek 
dan objek akan memiliki dampak terhadap peran pembaca dalam teks yang pada hakikatnya merupakan hasil negosiasi yang dilakukan oleh pembaca dan penulis (Sobari \& Faridah, 2012).

Eriyanto (2015) mengemukakan bahwa model Sara Mills dalam menganalisis wacana pemberitaan lebih menekankan pada posisi perempuan yang digambarkan dalam teks. Tingkat posisi subjek-objek lebih mengarah pada bagaimana peristiwa tersebut dilihat, dari persepsi sudut pandang siapa peristiwa itu diuraikan. Siapa tokoh yang mendapat posisikan sebagai pencerita (subjek) dan siapa diposisikan sebagai objek yang diceritakan. Apakah setiap aktor dan kelompok sosial memiliki kesempatan untuk menampilkan dirinya, sudut pandangnya, atau kehadiran dan sudut pandangnya ditampilkan melalui kelompok lain. Posisi penulis-pembaca menjelaskan bagaimana posisi tersebut diceritakan pada teks. Peran pembaca dalam memosisikan dirinya pada teks yang ditampilkan dan lebih condong pada kelompok apakah pembaca dalam mengidentifikasi dirinya.

Aktor yang menjadi objek korban pemerkosaan pada pemberitaan, yaitu anak perempuan berusia 13 tahun. Konteks berita terjadi di dalam rumah tangga. Berdasarkan strategi wacana yang digunakan oleh penulis terlihat bahwa "kisah pilu korban pemerkosaan" ini menjadi objek penceritaan, hal ini terbukti dengan penggunaan pemarkah seperti seorang bocah, kekerasan seksual, dipaksa menikah, pemerkosaan, memperparah trauma, dan korban kian terpuruk. Berawal dari pemilihan judul dengan verba pasif "Kisah Pilu Korban Pemerkosaan Dipaksa Menikah dengan Pelaku", wartawan merepresentasikan menonjolkan posisi korban perempuan sebagai sosok yang tidak berdaya. Diksi "dipaksa" bermakna suatu keadaan yang mendorong ke posisi atau keadaan tertentu dengan menggunakan kekuatan fisik maupun psikis. Eksploitasi perempuan dalam judul tampil dengan frasa "kisah pilu", sebab diketahui bahwa pembaca berita dan pada umumnya masyarakat lebih tertarik membaca atau menyimak hal-hal yang menimbulkan simpati. Lebih lanjut, representasi kelemahan perempuan yang ditampilkan dalam teks berita terdapat dalam data-data sebagai berikut.

(1) Korban pemerkosaan dipaksa untuk menikah dengan pelaku atau sang predator. Hal inilah yang terjadi di Kalimantan Timur tepatnya di Kabupaten Kutai Kartanegara di mana seorang bocah 13 tahun harus mengalami tindak kekerasan seksual hingga pemerkosaan yang dilakukan oleh Ayah tiri. Naasnya setelah 7 tahun perilaku tak bermoral ini baru diketahui oleh sang ibu, itu pun karena sang anak hamil 5 bulan. Sang ibu kandung tak menyangka, suami yang ia cintai dan ia layani sepenuh hati, tega melakukan tindakan keji tersebut kepada anak perempuannya. Mirisnya, sang anak sebutlah Dahlia akhirnya dipaksa menikah dengan ayah tirinya untuk menutupi malu yang membuat mereka hidup bertiga sebagai keluarga namun tak lagi sebagai ayah, ibu, dan anak melainkan Suami dan dua istri.

Terungkapnya perbuatan asusila yang ternyata sudah terjadi selama tujuh tahun, itu pun karena sang anak sudah hamil lima bulan. Seolah memberikan gambaran bahwa korban tidak melakukan hal apa pun hingga perilaku pemerkosaan tersebut terjadi selama tujuh tahun, seolah korban menerima, menjalani, bahkan menikmati keadaan tersebut. Kasus yang terjadi di dalam 
rumah tersebut seolah menyatakan bahwa korban tidak melakukan kegiatan perlawanan apa pun, seperti mencoba kabur saat pelaku bekerja atau tidak berdaya seperti saat mandi, tidur, dan sebagainya. Selama tujuh tahun seolah korban tidak meminta pertolongan kepada siapa pun, baik kepada tetangga, kepada ibu kandungnya sendiri, maupun melapor kepada pihak yang berwajib.

Pada berita tersebut penulis, yang dalam hal ini adalah seorang wartawan, tidak saja memosisikan korban sebagai perempuan yang lemah, tetapi sang ibu korban juga turut diberitakan dengan menggunakan perspektif gender yang menyatakan pria lebih berkuasa dan maskulin. Wartawan menggunakan pilihan klausa "ia layani sepenuh hati" pada kalimat "Sang ibu kandung tak menyangka, suami yang ia cintai dan ia layani sepenuh hati, tega melakukan tindakan keji tersebut kepada anak perempuannya". Pemilihan diksi "layani" mengacu pada infeoritas suami yang disebutkan di awal kalimat sebagai subjek. Pilihan kata dalam konteks pemberitaan tersebut semakin menegaskan definisi teori dominasi sebagai mereka yang berfokus pada 'cara laki-laki memiliki kekuasaan atas perempuan'. Pandangan tentang gender ini menunjukkan bahwa perempuan tidak berdaya sedangkan laki-laki yang berkuasa (Angjaya, 2021).

Kedudukan objek sebagai korban menjadi semakin lemah yang ternyata aktor perempuan lain yang memiliki tingkat kekuasaan lebih tinggi yaitu ibu kandung juga tidak berpihak kepadanya. Aktor ibu digambarkan memiliki peran inferior yang tidak memberikan pengaruh positif apa pun dalam keselamatan sang anak dari tindak asusila yang dilakukan oleh suaminya sendiri sehingga bisa hidup bertiga dengan tidak lagi sebagai ayah, ibu, dan anak. Namun, sebagai suami dan dua istri. Hal ini sejalan dengan yang dinyatakan oleh Purwanti \& Zalianti (2018) bahwa kekerasan seksual dapat terjadi bukan hanya di ruang publik, tetapi juga dapat terjadi di ruang domestik dengan korban yang dianggap lemah, yaitu perempuan dan anak-anak. Hal ini terjadi karena anakanak masih memiliki tingkat ketergantungan yang besar kepada orang dewasa sehingga rentan mendapat kekerasan seksual yang dilakukan oleh orang dewasa.

Subjektivitas gender yang dilakukan oleh penulis yaitu wartawan dilakukan dengan pilihan kalimat "Mirisnya, sang anak sebutlah Dahlia akhirnya dipaksa menikah dengan ayah tirinya untuk menutupi malu". Penggunaan kalimat pasif dengan verba "dipaksa" merepresentasikan posisi korban sebagai perempuan yang menjadi objek yang semakin tersudut ketika mendapatkan kekerasan seksual yaitu dipaksa menikah dengan ayah tiri yang memperkosanya untuk menutupi malu dikarenakan mengandung lima bulan. Penggunaan klausa aktif "untuk menutupi malu" merepresentasikan bahwa Dahlia (korban) yang justru menjadi pihak yang berjuang untuk mengatasi permasalahannya sendiri. Perspektif tersebut semakin merendahkan kaum perempuan seolah perempuan menjadi tumpuan kesalahan atas kehamilan akibat dari perbuatan pemerkosaan sehingga ia harus bertanggung jawab dengan menurut untuk dinikahi. Ambiguitas informasi juga terdapat dalam kalimat tersebut dikarenakan dalam teks tersebut wartawan tidak menjelaskan korban dipaksa menikah oleh siapa, apakah paksaan murni dari ibu kandung, ayah tiri, atau ibu kandung atas 
ancaman ayah tiri. Namun, berdasarkan kutipan teks tersebut dapat membuat pembaca berasumsi bahwa korban menikah dengan ayah tiri berdasarkan paksaan dari ibu kandung untuk menutupi malu setelah mengetahui bahwa korban sudah diperkosa selama tujuh tahun dan mengandung lima bulan.

Sosok anak yang lemah karena masih bergantung kepada orang dewasa mengakibatkan anak-anak tidak memiliki kekuatan dan keberdayaan dari ancaman untuk tidak menceritakan apa yang dialaminya kepada siapa pun. Kebanyakan kasus yang terjadi pada kekerasan seksual anak terungkap bahwa pelaku tindak kejahatan tersebut adalah orang dekat korban maupun yang memiliki dominasi tinggi, misalnya orang tua dan guru. Siapa pun dapat menjadi pelaku kekeran seksual terhadap anak. Pelaku akan menggunakan tipu daya, ancaman, tindakan kekerasan kepada anak sehingga anak tidak dapat melakukan perlawanan. Kekerasan seksual pada anak merupakan segala bentuk aktivitas seksual yang melibatkan anak sebelum mencapai Batasan umur tertentu berdasarkan usia yang telah ditetapkan oleh negara dan dilakukan oleh orang yang lebih tua darinya untuk kesenangan maupun aktivitas seksual (CASAT Programme, Child Development Institute; Boyscouts of America; Komnas PA:14)

Tentu saja jika pernyataan dalam berita tersebut memang bersumber dari aktor subjek sebagai ibu, maka posisi perempuan yang memiliki peran sebagai ibu korban akan dipertanyakan bagaimana pemikiran dan naluri keibuannya. Apakah ia jujur dalam menyampaikan sudut pandangnya atau terpaksa ia lakukan agar selamat dari ancaman suami. Kasus pemerkosaan pada perempuan merupakan salah satu contoh bagaimana rendahnya posisi perempuan dalam kepentingan seksual laki-laki. Perempuan yang menjadi citra sebagai objek seksual laki-laki berakibat pada kehidupan sehari hari perempuan yang identik dengan mendapatkan kekerasan, perlakuan paksa, dan perbuatan penyiksaan baik secara fisik maupun psikologis sehingga menjadi daya tarik media massa dalam memusatkan wanita sebagai pemberitaan Kedudukan wanita sebagai korban merupakan akibat dari citra perempuan yang selalu tunduk terhadap laki-laki dan tidak memiliki kekuatan dalam melampaui kekuasaan laki-laki sehingga perempuan dalam media massa selalu diidentikkan dengan penggambaran yang tertindas (Novianty \& Burhanudin, 2020).

Dominasi laki-laki kepada perempuan secara tidak langsung diterima oleh masyarakat dai generasi ke generasi. Indonesia merupakan salah satu negara dengan hegemoni patriarki dengan posisi bapak yang memiliki kekuasaan dalam keluarga (Dalem, 2013). Patriarki merupakan penggambaran sistem sosial pada pihak laki-laki yang mengendalikan kekuasaan terhadap perempuan. Laki-laki memiliki kedudukan yang lebih tinggi dibandingkan dengan perempuan. Adanya perbedaan yang jelas antara peran laki-laki dan perempuan dalam kehidupan bermasyarakat, khususnya kehidupan dalam keluarga. Laki-laki menjadi pemimpin dengan otoritas yang mencakup kontrol pada sumber daya ekonomi dan pembagian dalam peran kerja di keluarga. Hal ini yang menjadikan perempuan memiliki akses si sektor publik dengan akses 
yang lebih terbatas dibandingkan dengan laki-laki (Dalem, 2013). Data selanjutnya yaitu sebagai berikut.

(2) Melihat dan mendengar kejadian ini, Tim Reaksi Cepat Perlindungan Perempuan dan Anak atau TRC PPA Provinsi Kalimantan Timur geram dan melakukan komunikasi dengan korban, Ibu Kandung korban, keluarga korban hingga tokoh masyarakat setempat, akhirnya disepakati kasus ini dibawa ke ranah hukum, karena menurut Rina Zainun ketua TRC PPA Kaltim kasus ini adalah sebuah kejahatan yang harus dilaporkan dan pelaku harus mendapat hukum yang setimpal. Saat ini kasus sedang berproses di meja hijau dan korban telah melahirkan anak buah hasil pemerkosaan.

Rina menyayangkan kasus seperti ini terus terjadi, baik pemerkosaan oleh oknum Ayah Tiri, Ayah Kandung hingga tindak pelecehan seksual di dalam rumah tangga. Menurutnya, akibat seorang perempuan tidak bekerja, pasrah dan mengantungkan diri kepada Suami sehingga siap menerima perilaku apa pun hingga sebuah dosa besar yakni memperkosa anak kandungnya sendiri, oleh karena itu Rina mengajak perempuan Kaltim untuk bekali diri dengan keterampilan atau tetap bekerja agar tidak diperlakukan semena-mena oleh oknum suami.

Pada kutipan di atas, perlakuan yang dilakukan oleh aktor lain sebagai TRC PPA Kaltim melakukan tindakan yang berpihak kepada korban dengan memberikan hukuman kepada pelaku pemerkosaan, tetapi tidak menjelaskan langkah apa yang dilakukan pascakasus tersebut apakah memberikan perlindungan, penyembuhan secara psikologis, maupun perawatan kepada korban dan anak yang telah dilahirkannya. Hal ini seolah memberikan kesan kepada pembaca bahwa setelah pelaku dipenjara maka masalah tersebut telah selesai dan korban yang menjadi objek cerita tersebut sudah tidak dipedulikan lagi kondisinya. Hal ini yang akan membuat pembaca seolah korban kasus pemerkosaan tidak memiliki dampak negatif dan perspektif tersebutlah yang akan semakin melemahkan posisi perempuan. Hal ini senada dengan yang dinyatakan oleh Mills (1991) bahwa penggambaran sebagai perempuan yang lemah dan bergantung pada laki-laki untuk perlindungan.

Kekerasan seksual berakibat pada timbulnya dampak traumatis. Sebagian besar kasus kekerasan seksual tidak terungkap karena adanya penyangkalan. Kekerasan seksual yang terjadi pada anak-anak akan menjadi lebih sulit karena anak-anak tidak menyadari bahwa dirinya telah menjadi korban kekerasan seksual. Selain itu anak-anak memiliki ketakutan untuk melaporkan tindak kekerasan seksual yang terjadi dan memiliki kesulitan dalam mempercayai orang lain sehingga peristiwa kekerasan seksual yang terjadi hanya dirahasiakan karena anak merasa bahwa kasus kekerasan tersebut hanya membuat nama keluarga menjadi tercoreng. Akhirnya anak menjadi powerlessness, yaitu adanya rasa tidak berdaya dan tersiksa pada korban pada saat mengungkap kejadian pelecehan seksual tersebut (Noviana, 2015)

(3) Menurutnya, akibat seorang perempuan tidak bekerja, pasrah dan mengantungkan diri kepada Suami sehingga siap menerima perilaku apa pun hingga sebuah dosa besar yakni memperkosa anak kandungnya sendiri, oleh karena itu Rina mengajak perempuan Kaltim untuk bekali diri dengan keterampilan atau tetap bekerja agar tidak diperlakukan semena-mena oleh oknum suami. 
Realitas kondisi perempuan yang tidak bekerja seperti yang diungkapkan oleh Rina dalam teks berita tersebut senada dengan yang dikatakan oleh Sobari \& Faridah (2012) bahwa secara umum masyarakat memandang pihak lali-laki memiliki peran menjadi nakhoda dalam lingkungan keluarga dan peran dalam pemberian nafkah.. Perempuan hanyalah sebagai pengurus rumah dan pendidikan anak-anaknya. Pilihan frasa "siap menerima" merepresentasikan perempuan sebagai korban yang seakan dianggap layak diperlakukan seperti itu oleh pria. Selanjutnya, wartawan memosisikan seolah posisi perempuan menjadi korban kekerasan seksual disebabkan karena kesalahan perempuan yang tidak memiliki kemampuan dalam hal finansial bukan dari kesalahan pria yang tidak mampu mengontrol pikiran kotor dan hasrat seksualnya. Hal ini dapat memberikan kesan kepada pembaca tentang betapa rendahnya penghargaan laki-laki terhadap perempuan, seolah perempuan hanya sebagai objek pemuas nafsu dan memiliki posisi yang semakin lemah ketika ia tidak berdaya secara finansial. Senda dengan hal tersebut Mills (2001) mengungkapkan whereas a straight female might be interpreted as displaying submissiveness to males, yaitu perempuan diinterpretasikan dengan menunjukkan ketundukannya kepada laki-laki. Ketundukan ini terjadi karena perempuan memiliki ketergantungan kepada laki-laki secara finansial.

(4) Dari ramainya polemik ini, Ustad Pink Al-Koetai mengingatkan bagi para perempuan yang ingin menikah dan telah memiliki seorang anak perempuan untuk lebih berhatihati dalam mencari suami, selain itu Ustad Pink juga memberi saran ketika telah menikah sebaiknya anak perempuan yang belia ini, hidup terpisah dari ayah tirinya, bisa dengan menitipkannya kepada nenek atau kakeknya atau di sekolahkan di asrama hingga pesantren agar terhindar dari hal-hal yang tidak diharapkan tersebut.

Ketidakberpihakan wartawan, atau narasumber, terhadap perempuan direpresentasikan pula melalui kalimat "Ustad Pink Al-Koetai mengingatkan bagi para perempuan yang ingin menikah dan telah memiliki seorang anak perempuan untuk lebih berhati-hati dalam mencari suami". Penggunaan verba aktif "mengingatkan" yang ditujukan kepada para perempuan seolah menegaskan bahwa dalam kasus ini yang salam adalah perempuan, seharusnya perempuanlah yang diharapkan dapat memilih suami dengan baik, hingga perempuanlah yang harus di tempatkan jauh dari laki-laki dewasa meskipun itu ayahnya sendiri. Padahal, kalimat tersebut dapat diubah menjadi sudut pandang lain agar pro gender, seperti misalnya menjadi mengingatkan bagi para laki-laki untuk mampu bersikap dewasa dan berhati-hati dalam mengendalikan hawa nafsu.

Perkosaan yang dialami korban mencitrakan bahwa perempuan menempati posisi yang lemah dan tidak memiliki keberdayaan terhadap ancaman yang mengintai dengan lebih memberikan saran atau mengingatkan kaum perempuan agar lebih menyeleksi calon suami dan menjauhkan anak kepada ayah tirinya. Berita tersebut mencitrakan seolah perempuan sebagai penyebab sumber dari awal mula kasus pemerkosaan dengan adanya korban bersama pelaku dalam satu atap. Ketimpangan ini tampak karena peringatan hanya 
ditujukan kepada kaum perempuan tetapi tidak kepada kaum pria, seolah pria tidak menjadi penyebab dalam terjadinya peristiwa tersebut.

Berita tersebut dipaparkan berdasarkan peristiwa yang terjadi yang muncul karena uraian dari aktor lain sebagai subjek pencerita, bukan berdasarkan keterangan korban atas apa yang dialaminya. Teks berita pada media tersebut memberikan gambaran bagaimana posisi subjek dan objek penceritaan yang ditampilkan dalam teks memberikan gambaran kepada pembaca. Pada teks berita yang ditampilkan terdapat bias gender sebab peristiwa yang dijabarkan tidak diceritakan melalui sudut pandang perempuan sebagai korban.

\section{Penutup}

Berdasarkan analisis teks dengan pendekatan analisis wacana kritis Sara Mills disimpulkan bahwa pemberitaan Kisah Pilu Korban Pemerkosaan Dipaksa Menikah dengan Pelaku yang terbit dalam media massa daring RRI Samarinda berisi deskripsi uraian dari aktor lain sebagai subjek pencerita, bukan berdasarkan keterangan korban atas apa yang dialaminya. Teks berita tersebut memberikan gambaran terkait posisi subjek dan objek penceritaan dan menentukan bagaimana teks hadir kepada pembaca. Teks berita yang ditampilkan tersirat bias gender, karena peristiwa yang terjadi tidak diungkapkan dalam sudut pandang perempuan sebagai korban. Ketidakberpihakan wartawan pada posisi perempuan direpresentasikan melalui penggunaan pemarkah seperti: seorang bocah, kekerasan seksual, dipaksa menikah, pemerkosaan, memperparah trauma, siap menerima, korban kian terpuruk, dan mengingatkan bagi para perempuan.

\section{Daftar Pustaka}

Angjaya, S. (2021). the Power of Bu Tejo and Dian? the Analysis of Feminist Power Relation in the Film Tilik. Capture: Jurnal Seni Media Rekam, 12(2), 132-159. https://doi.org/10.33153/capture.v12i2.3613

Badara, A. (2014). Analisis Wacana: Teori, Metode, dan penerapannya pada Wacana Media. Kencana.

Dalem, D. N. (2013). Faktor-Faktor yang Mempengaruhi Bias Gender Penggunaan Kontrasepsi pada Pasangan Usia Subur di Desa Dawan Kaler Kecamatan Dawan Klungkung. Piramida, 8(2), 93-102. https://ojs.unud.ac.id/index.php/piramida/article/view/7001

Dawn, E., Descrates, L., \& Collier, M. A. (2011). Gender Role Portrayal and the Disney Princesses. Sex Rolex, 64, 555-567. https://link.springer.com/article/10.1007/s11199-011-9930-7

Eriyanto. (2015). Analisis Wacana. Yogyakarta: LKiS.

Kiprotich, A. J., \& Chang 'orok, J. R. (2015). Gender Communication

Stereotypes: A Depiction of the Mass Media. IOSR Journal Of Humanities And Social Science, 20(11), 69-77. https://doi.org/10.9790/0837201156977

Lesmana, I. B. G. A. S., Udasmoro, W., \& Hayuningsih, A. A. C. (2021). 
Konstruksi dan Kontestasi Kuasa Perempuan pada Naskah Drama Les Bonnes Karya Jean Genet. Diglosia: Jurnal Kajian Bahasa, Sastra, dan Pengajarannya, 4(1), 65-78. https://doi.org/10.30872/diglosia.v4i1.124

Mills, S. (1991). Discours of Diferensi Discours of Diferensi. London: Routledge. Mills, S. (2001). Discourse. London: Routledge.

Mintarsih, A. R. (2019). Media coverage of a shelter for abandoned children in Indonesia: A feminist critical discourse analysis of the representation of female migrant workers. Pertanika Journal of Social Sciences and Humanities, 27(4), 2621-2634. http://www.pertanika.upm.edu.my/pjssh/browse/regularissue?article $=\mathrm{JSSH}(\mathrm{S})-1094-20$

Noviana, I. (2015). Kekerasan Seksual terhadap Anak: Dampak dan Penanganannya. Sosio Informa, 1(1), 13-28. https://doi.org/10.33007/inf.v1i1.87

Novianty, F., \& Burhanudin, M. (2020). Bias Gender dalam Berita "Kasus Driver Taksi Online Setubuhi Mahasiswi Asal Malang di Dalam Mobil" (Analisis Wacana Kritis Sara Mills). Orasi, 11(1), 71-76. http://dx.doi.org/10.24235/orasi.v11i1.6240

Purwanti, A., \& Zalianti, M. (2018). Strategi Penyelesaian Tindak Kekerasan Seksual Terhadap Perempuan san Anak Melalui RUU Kekerasan Seksual. Masalah-Masalah Hukum, $47(2)$, 138. https://doi.org/10.14710/mmh.47.2.2018.138-148

Sobari, T., \& Faridah, L. (2012). Model Sara Mills dalam Analisis Wacana Peran dan Relasi Gender. Semantik, 6(1), 88-99. http://ejournal.stkipsiliwangi.ac.id/index.php/semantik/article/view/464/333 